FAYVISHENKO Diana,

$\mathrm{PhD}$ (Economic Sciences), Associate professor Department of journalism and advertising

Kyiv National University of Trade and Economics,

19, Kyoto str., Kyiv, 02156, Ukraine

E-mail:fayvishenko.ds@gmail.com

ORCID: https://orcid.org/0000-0001-7880-9801

\title{
DIGITAL TECHNOLOGIES IN MEDIA DESIGN
}

The main aspects of media content development and media design concept are considered in the article, the development of the concept of media design, analyzes the main modern tendencies of information visualization, investigates the influence of the media on all processes of public life, obtained the synergetics of information and digital society formed the direction of "mediadesign". Analyzing the development of media design and how it is presented in a particular industry are promising scientific and practical areas worldwide. It is necessary to adapt the latest technologies to the present.

Keywords: media content, media design, trend, communication, advertising.

Файвишенко Д. Цифровые технологии в медиадизайне. Рассмотрены главные аспекты разработки медиаконтента и концепции медиадизайна, проанализированы основные современнье тенденции визуализации информации. Исследовань влияние медиа на все прочессы общественной жизни, синергетика информационного и цифррового общества, направление медиадизайна, его представления в конкретной отрасли, адаптация к новейшим технологиям современности.

Ключевые слова: медиаконтент, медиадизайн, тренд, коммуникация, реклама.

Background. Today, in a context of intense competition, special attention is to the context of media history, the theory and practice of media culture, media philosophy, media policy, media management and media pedagogy, not taking into account the needs of various social groups, as well as the use of digital trends in the communication procotory. The main task of mediology is to ensure the healthy lifestyle of humankind in the system of global social communications, which can be solved with the help of not only theoretical knowledge of the media system management (as defined in the article), but also by using the application of the various types of media functioning principles, such as: marketing analysis of the environment (for which) the media work, segmentation of its (media) target audience, identifying the needs of the product or service users (generating media content) and visual presentation.

Analysis of recent research and publications. Confirmation of the medialogy development and media design is found in the work of many scholars: V. Vartanova, O. Vasilieva, O. Gonsharuk, V. Ovsharek, S. Pryshchenko, V. Shevchenko, S. Chyrchyk, D. Richards, D. Crockett, S. Janicke [1-10]

(C) Fayvishenko D., 2019 
however, even today the topic is quite relevant, media design is considered as a modern science, draws attention to the transformations that take place today in communication theories, the number and variety of alternative media in all forms. In general, it is necessary to focus on the issues of the media design formation and development, which requires further complex interdisciplinary research.

The aim of our research: consider the development of the concept of media design, conduct a review of the main modern trends in the visualization of information, analyze the impact of the media on all processes of social life through the synergy of the information and digital society, focus on the direction of "media design", visual interdisciplinary research.

Materials and methods. Research findings have served as global trends in the development of media design in the world. The paper used general scientific and special methods of observation, methods of generalization, comparative analysis, structural analysis and systematization, system analysis and visualization of information in the media space.

Results. Tense competition, latest technological advancement, globalization, observed today make visual communication an important part of the mass media system. The second half of the $20^{\text {th }}$ century was characterized by a trend of journalists' visualization, which resulted in greater number of studies devoted to the visual media. More attention is paid to the concept of media design, the trends of modern information visualization.

On the one hand, the works suggest the use of mass media to interact in small groups and communities; on the other hand, researcher R. Rice [11] focuses on new mass media that require a radical review of communication research, the implementation of intellectual and transformational changes.

V. Shevchenko [6] and many researchers focus on the interactive environment, which is today a niche for communication researchers.

L. Vasilik [12] states that the media industry is changing rapidly today, the media face the development and combination of various formats. According to the author, these changes will set new scientific issues for the researchers, related to the development of a new or refinement of traditional terminology tools.

D. Richards focuses on individuality and uniqueness through the use and combination of essays with computer technology and the ability to create better content in media space [8].

Media design is the artistic and technical design and presentation of information, taking into account the ergonomics of working with information sources and services, the functionality of presentation of information, the aesthetics of the visual forms of its presentation and the psychological criteria of perception by its audience.

Now the tendency is getting stronger, the visual information is penetrating into the communication environment of different mass media. The visualization has been used by all mass media, except for the radio (including the press, the videos, the television, the cinema, the computer and mobile communication) figure 1 [13]. 


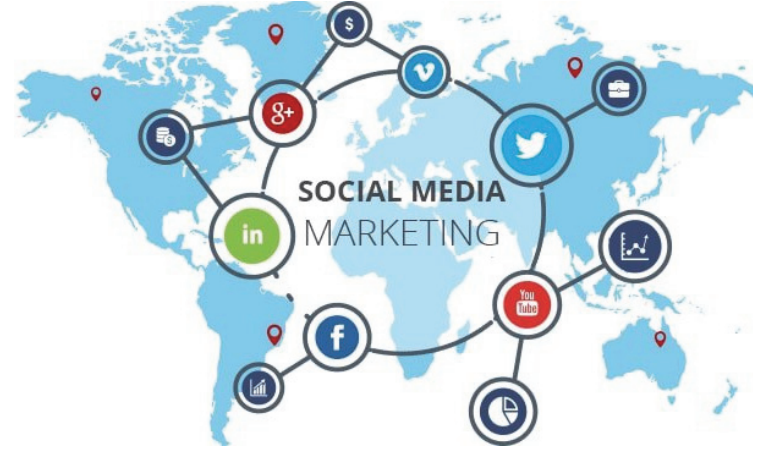

Figure 1. Visual size comparison [13]

Visual communication plays a large role and replaces text communication. Consumer audience does not perceive an avalanche of information without visual perception; respondents try to evaluate everything that is happening without studying the read texts deeply, most often just looking at pictures [14].

The visual channels of information are now being brought to the first position among all the information channels. The modern media environment is within the period of re-orientation and change of values, re-formatting the information and data transmission channels, the search for new effective methods of influence on the audience, so the media is characterized by active use of illustrations and illustrative material, the use of various technologies of information visualization. Data visualization is a method of processing and demonstration of great massifs of information, which makes it an effective way of communication [6]. The most popular social networks that use media content. Recent studies suggest that digital values are effecttive and that information is represented. Quantitative characteristics, visualization of content through digital data, make it possible to present informative longrides in the media with greater factual accuracy and reliability [8].

When visualizing data, it is necessary to maintain a balance, equally distribute information between numbers and text. The main means of presenting information can also include: the calculation of the ratio, comparison, visual representation, explanation. Emphasis is placed on the importance of the emotional component and the perception of information through the visualization of numbers. Digital information can also be presented through the game principle in modern journalism. The game can be built on the representation of units of measure, exaggeration of values, irony and color picture figure 2 [15].
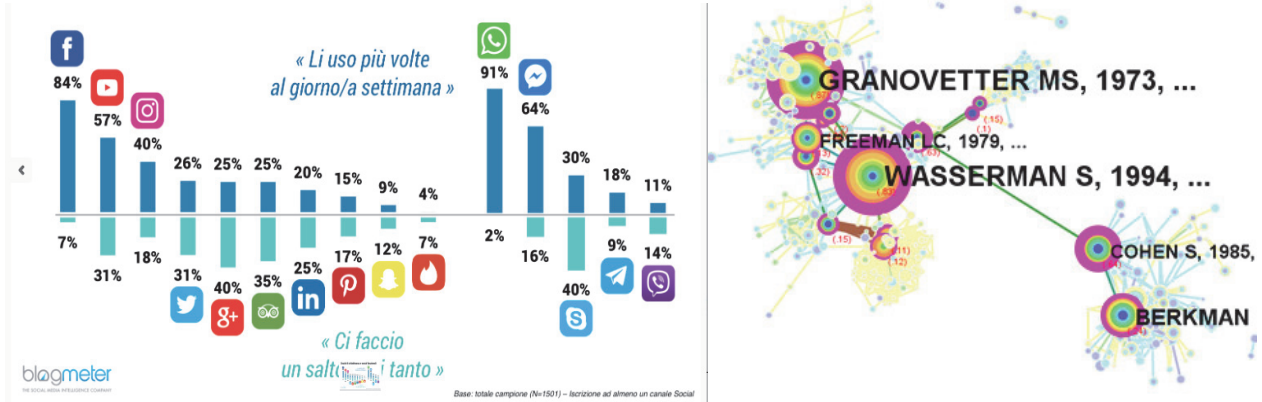

Figure 2. Exemple of visualization of the frequency of using social networks in Italy [15] 
The visual content of information in social media used to be presented mostly by photos and pictures, but now the user is focused on creating extraordinary and creative way of presentation. It makes the work of SMM easier and accelerates the spread of unusual by from information visual filling-ins. actual use of brand hash tags, font creativity and color brightness, the delivery of media content through various graphic elements enhances visual perception and clarity; an opportunity to make a comment using animated pictures [20].

"Today, consumers are looking for more positive, optimistic and inspirational content in social networks, because the world, especially the digital sphere, can sometimes be very controversial," - shared Sarah Traverso, director of the Coca-Cola group.

Current trends in media design are that there is a constant update of the content of news feeds on social networks, a constant provision of more comprehensive linguistic and visual presentation of information to consumer audiences, whose number is constantly growing across different social platforms. All images are graphic and are presented in brand colors of the brand. "We took a step back, looked at the content on our platforms and realized that while we are proud of this work, it does not make sense that the content has one holistic view," - says Kung-Shakleman [16] (figure 3).

Adding target buttons for involving greater audience while providing information about an event. In this case the important elements of the page are the following: the name of the event, the programme and itinerary and the venue.

Smile and emoji are important for SMM to increase attention and effect. So the online communication does not give a chance to express emotions, while emoji and graphical elements will help make a better contact with your target audience.

Creation of brand photos

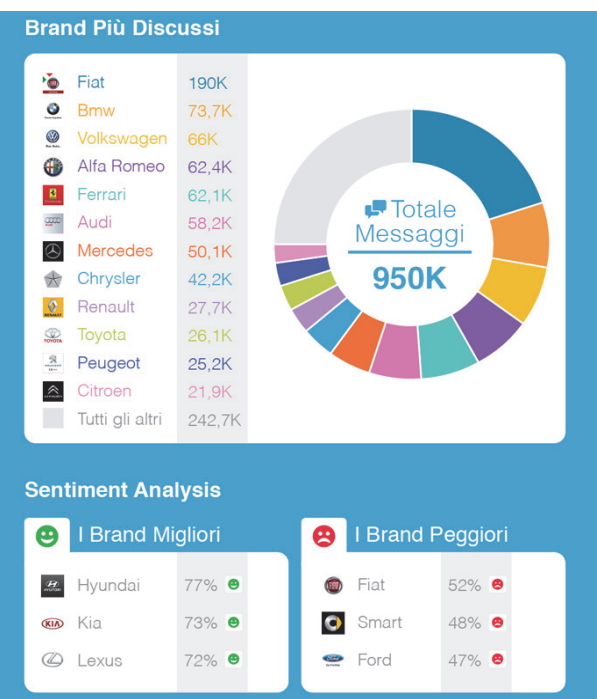

Figure 3. Exemple of visualization of automotive brand networks in Facebook [17] and video collages. Unusual content will make a great SMM effect. For making you content different from the common one, different methods, combined approaches and styles are used to create the content. You may focus on experiment as a key to the success in social media promotion, which is one of the main internet marketing tools alongside the web-site promotion and context ads.

Now the most popular tools are infographics, interactive maps and submitting information in blocks. National Geographic journal, The Times Roman newspaper use infographics frequently since the visualized infor- 
mation is easy to perceive. As an example, the maps of the US states and their "ecological imprints", Quarterly Real Estate Graphic. Such maps are easy to create using Infogr.am figure 4 [18].

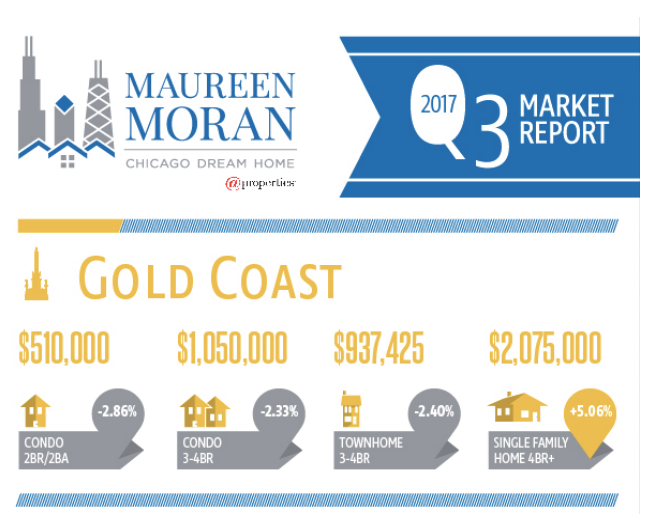

Figure 4. Quarterly Real Estate Graphic, Designer: Josh Wise [18]

Create media books and landing pages to visualize content. As an example, Uberflip is today creating a platform that delivers a call to action in the social media space. You can control the flow of content through the platform and receive comments, feedback. Medicontent is the most effective way to maintain meaningful relationships, exchange experiences, to succeed and to reach your full potential. Uberflip is a content experience platform that brings together all your content, all information (blog articles, ebooks, videos, white wallpapers, and more), or the purpose of creating, managing, optimizing every stage of the consumer journey. Media design helps you to understand and remember information. Visuals are much better perceived than text, digital or spreadsheets. Such important information is lost in the flow of large volumes of text. By visualizing, you can show the user what is often lost. Media designers and content producers can make effective use of a person's natural feature to deliver a wealth of data.

Well-elaborated visualizations, especially personalized ones, render information in the best way. It is caused by the fact that a user reacts to the design in the same way as to the content of the visualization. If its general design or some elements appeal to the user's experience, special features, concerns, etc. the user's reaction to them and their visual impact are stronger. His / her memory is going to keep them figure 5 [5].

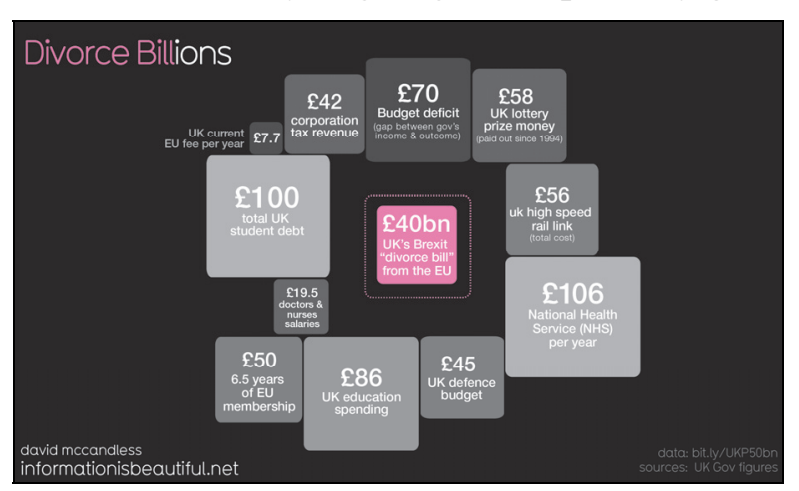

Figure 5. Visualization of data [18]

The focus is made on openness, sincerity, and brightness. The main trend is mass individualization. The design is not for all but for each of us. Designers are thinking about the electric design, mixing styles and stylistics reflecting a personality and his/her passions in the best way. The slogan is as follows: to ignore tendencies and express emotions.

Contrasting prints and ornaments, a powerful mixture of different styles and epochs, rejecting minimalism, brought by Scandinavians and dominating during the recent years. Consumers would like to express 
themselves, and maximalism style (sometimes on the edge of kitsch) allows them to do it. "The consumers do not want to be told stories (they tell stories themselves), they want to empathize and experience something new. As soon as the pace of life has accelerated, one can trace how the notions of good and bad taste, high and low brands, liberation of imagination and abstract representation are all being mixed" [19].

In this way, the content visualization is of great importance today for perceiving and communicating information, which makes it possible to represent a text as new, modern and up-dated, with a designer's interpretation, adequate perception, making it a main instrument in a struggle for consumers in the fast changing medium of the Internet. Thanks to the successful visualization, you can quickly attract the target audience and influence the speed of making a decision on the purchase, as well as increase loyalty to the brand as a whole.

Conclusion. A presentation of understanding of the media design is presented, a survey of the main current trends of visualization of information, a flow of mass media on all processes of suspension of life is analyzed the synergy of information and digital society, the direction of "media design", and the visual interdisciplinary research is presented.

\section{REFERENCES}

1. Vartanova, E. L. (2016). Antropologija media: industrial'nyj i filosofskij povorot $\mathrm{k}$ cheloveku. Interes $\mathrm{k}$ cheloveku kak tendencija razvitija nauki [Anthropology of media: industrial and philosophical turn to human. Interest in the person as the trend of the development of science]. V. K. Mal'kova, V. A. Tishkov (Ed.). Moscow. IJeA RAN [in Russian].

2. Vasyl'jeva, O. S., Vasyl'jeva, I. V., \& Pryhod'ko, I. O. (2017). Infografichni skladovi dyzajnu [Infographic design components]. Teorija i praktyka dyzajnu Design theory and practice: collection of scientific papers / Technical aesthetics. (Vol. 13). (pp. 140-144). Kyiv: Dija [in Ukrainian].

3. Goncharuk, O. V., Dovzhenko, I. B., \& Ovcharek, V. Je. (2017). Paralaks i mnozhynnist' smysliv: do problemy adaptacii' innovacijnyh tehnologij u sferi fotovideodyzajnu [Parallax and the multiplicity of meanings: to the problem of adapting innovative technologies in the field of photographic video design]. Visnyk KNUTD - KNUTD Bulletin, 5 (114), 235-241 [in Ukrainian].

4. Ovcharek, V. Je., \& Myronenko, V. O. (2016). Osoblyvosti prezentacii' fotografichnyh tvoriv na mystec'kyh ta torgovo-promyslovyh vystavkah [Features of presentation of photographic works at art and trade and industrial exhibitions]. Teorija ta praktyka dyzajnu - Design theory and practice: collection of scientific papers / Technical aesthetics. (Vol. 10). (pp. 113-125) [in Ukrainian].

5. Pryshchenko, S. (2017). Advertising graphics in the structure of integradet art discipline Design of Advertising. Visnyk Nacional'noi' akademii' kerivnyh kadriv kul'tury i mystectv - Bulletin of the National Academy of Art and Culture Leaders, 4, 207-211[in English]. 
6. Krosmedia: kontent, tehnologii', perspektyvy (2017) [Cross media: content, technologies, perspectives]. V. E. Shevchenko (Ed.). Kyiv: Kafedra mul'tymedijnyh tehnologij i mediadyzajnu Instytutu zhurnalistyky Kyi'vs'kogo nacional'nogo universytetu imeni Tarasa Shevchenka [in Ukrainian].

7. Chyrchyk, S. (2016). Foreign experience of design education. Modern Science Moderní věda. Praha. Nemoros, 6, 97-104 [in English].

8. Richards, D. E. (2016). Ulichnyj sketching. Kak ispol'zovat' nabroski ot ruki $v$ professional'nom dizajne [Street sketching. How to use freehand outline in professional design]. Moscow. Popurri [in Russian].

9. Crockett, D. (2016). Direct visualization techniques forthe analysis of imagedata: The slice histogramand the growing entourageplot. International Journal for Digital Art History, 2 [in English].

10. Janicke, S., Focht, J., \& Scheuermann, G. (2016). Interactive visual profiling of musicians. IEEE Transactions on Visualization and Computer Graphics. (Vol. 22), 1. (pp. 200-209) [in English].

11. British Sky Broad casting Group plc (2005). SWOT Analysis. Datamonitor. (pp. 5-8) [in English].

12. Vasylyk, L. Je. (2013). Kros-media jak trend suchasnoi' zhurnalistyky [Crossmedia as a trend in contemporary journalism ]. Naukovi zapysky Instytutu zhurnalistyky - Scientific notes of the Institute of Journalism. (Vol. 52). (pp. 297-300) [in Ukrainian].

13. Social media marketing. pitdesigns.com. Retrieved from https://pitdesigns.com/en/ social-media-marketing-in-erbil [in English].

14. Vajshenberg, Z., Kljajnshtojber, G. J., \& P'orksen, B. (2011). Zhurnalistyka ta media [Journalism and media]. Dovidnyk. P. Demeshko ta K. Makjejev (Eds. Trans). V. Ivanov, O. Voloshenjuk (Eds.). Kyiv: Centr Vil'noi' Presy, Akademija Ukrai'ns'koi' Presy [in Ukrainian].

15. Keyformat. www.keyformat.it. Retrieved from https://www.keyformat.it/en/ abitudini-utilizzo-social-media-italiani-studio-blogmeter [in English].

16. Kung-Shakleman, L. (2000). Inside the BBC and CNN: managing media organizations. London/New York: Routlege [in English].

17. Brand automotive. vincos.it. Retrieved from https://vincos.it/2014/05/16/ analisi-automotive-2014 [in English].

18. World Comparison Infographic. visual.ly. Retrieved from https://visual.ly/community/ infographic/other/world-comparison-infographic [in English].

19. Wired for Empathy: How and Why Stories Cultivate Emotions. firesteelwa.org. Retrieved from http://firesteelwa.org/2015/07/wired-for-empathy-how-and-whystories-cultivate-emotions [in English].

20. 100+ Creative Presentation Ideas That Will Delight Your Audience. visme.co. Retrieved from https://visme.co/blog/creative-presentation-ideas [in English].

The article submitted to editor's office on 10.06.2019.

Файвішенко Д. Цифрові технології у медіадизайні.

Постановка проблеми. В умовах насиченої конкуренції особливу увагу привертають медіа, теорія та практика медіакультури, використання иифррових тенденцій у комунікаційному просторі. Основний акиент зроблено на забезпеченні здорового способу життя людства в системі глобальних сочіальних комунікацій, яке може бути вирішено за допомогою не лише наукових теорій управління системою 3МI, а й завдяки використанню прикладних засад функиіонування різних типів медіа та візуальної подачі.

ISSN 1727-9313. ВIСНИК КНТЕУ. 2019. No 5 
Аналіз останніх досліджень і публікацій показав, щуо попри наявність окремих наукових доробок, існує необхідність подальшого вивчення поняття медіадизайну та формування джерельної бази, щуо відображує систематизацію изього знання. 3 урахуванням стрімкого впливу масмедіа на всі прочеси суспільного життя є необхідність адаптування новітніх технологій до сьогодення.

Мета статті - розглянути поняття медіадизайну, провести огляд основних сучасних тенденцій візуалізащії інформачії, проаналізувати вилив засобів масової інформачії на всі прочеси суспільного життя через синергію інформації та циифрового суспільства, орієнтацію на напрям "медіадизайн", візуальні міждисциилінарні дослідження.

Матеріали та методи. У роботі використано загальнонаукові та спеціальні методи спостереження: узагальнення, порівняльний аналіз, структурний аналіз, системний аналіз та візуалізація інформації у медіапросторі.

Результати дослідження. Сучасний стан медіадизайну проаналізовано на основі вітчизняної та світової інформації, огляду основних тенденцій візуалізації інформації, аналізу впливу масмедіа на всі процеси суспільного життя, використання прийомів та інфографіки при створенні медіадизайну.

Висновки. Представлено розвиток поняття медіадизайну, проведено огляд основних сучасних трендів візуалізації інформачї, проаналізовано вплив масмедіа на всі процеси суспільного життя, отримано синергію інформаційно-цифрового суспільства, сформовано напрям "медіадизайн", представлено візуально міждисиіплінарні дослідження.

Ключові слова: медіаконтент, медіадизайн, тренд, комунікація, реклама. 